\title{
ANALYSIS OF AFFORDABILITY OF THE FIRST LINE ANTIHYPERTENSIVE DRUGS FOR THE UKRAINIAN PATIENTS
}

\section{L.V.Iakovlieva, M.M.Portyanka}

\author{
National University of Pharmacy \\ Key words: hypertension; coefficient of the solvency adequacy; affordability ratio; unified clinical protocol
}

\begin{abstract}
Hpertension is one of the major medical and social problems in our country and around the world due to its significant prevalence and serious consequences, and this fact has determined the object and the aim of our study. The aim of the study was to determine affordability of the first line antihypertensive drugs recommended by the Unified Clinical Protocol of Medical Care to Patients with Hypertension (UCPMC) and presented at the pharmaceutical market of Ukraine in 20132014 for the Ukrainian patients. Two indicators were used to characterize the level of affordability of antihypertensive drugs: Ca.s and A. Ca.s determines the percentage of the average wage to be paid by the patient for the price of 1 package of a drug, and the greater value it has, the less affordable is the drug. The affordability ratio A shows the relationship between the growth of the living wage based on the index of growth of the drug price and the increase in the minimum wage. The study has revealed that the first line antihypertensive drugs (TNS) on the basis of 36 INNs and 35 fixed combinations were presented at the Ukrainian pharmaceutical market in 2013 and 2014. In 2014 the increase in the value of Ca.s for all INNs and all combinations was observed. It indicates the tendency towards decrease in affordability of drugs. However, by the absolute value most of Ca.s values are still in the range of highly affordable drugs, and it is provided by the presence of a great number of generic drugs at the market. The dynamics of A values has also confirmed the tendency towards decrease in affordability of antihypertensive drugs and their combinations. For example, 9 INNs and 5 combinations had $A<1$ in 2013, and 32 INNs and 28 combinations - in 2014. This tendency of decrease in affordability of drugs necessitates introduction of socioeconomic measures to support the impoverished population of Ukraine; these measures may include reimbursement of expenditures on antihypertensive therapy at the expense of the state.
\end{abstract}

Cardiovascular disease ranks

first among causes of death, disability and inability to work of the population. Hypertension (HTN) is the most common chronic disease that leads to development of a variety of vascular and cardiac complications [2].

In Ukraine, the prevalence of HTN among circulatory diseases is $46.8 \%$, and almost half of the patients have cardiovascular diseases (CVD). Among the costs for the treatment of CVD the costs associated with the in-patient treatment of patients (60\%) prevail [4].

Hypertension is one of the major medical and social problems in our country and around the world due to its significant prevalence and serious consequences. According to the WHO experts in the future mortality from hypertension will increase, firstly, due to aging of the population, and secondly, - to increasing prevalence of such risk factors as obesity, physical inactivity, diabetes, smoking, psycho-emotional stress, etc., in the population of many countries [3].

Hypertension is a disease of the cardiovascular system that develops due to the dysfunction of vasoregulative centers, followed by disturbances in the system of neurohumoral and renal mechanisms, and is characterized by increased blood pressure, secondary functional and organic changes in target organs [5].

The most relevant groups of drugs to treat hypertension include the following first-line drugs: angiotensin-converting-enzyme inhibitors (ACE inhibitors), calcium antagonists (CA), beta-blockers ( $\beta$-blockers), angiotensin II receptor blockers (ARBs) and diuretics [7].

It is quite logical for each person to obtain the maximum therapeutic effect at minimum cost. But the high incidence rate, frequency of complications, disability and administration of drugs

L.V.lakovlieva - Honored Worker of Science and Technology of Ukraine, professor, Doctor of Pharmacy, head of the Department of Pharmacoeconomics of the National University of Pharmacy (Kharkiv)

throughout later life indicate significant economic costs for patients. Taking all this into account it is relevant today to conduct the pharmacoeconomic evaluation of the treatment of hypertension and substantiate expediency for selecting a drug to optimize costs [8].

The aim of the study is to determine affordability of the first line antihypertensive drugs recommended by the Unified Clinical Protocol of Medical Care to Patients with Hypertension (UCPMC) in Ukraine in 2013-2014 for the Ukrainian patients.

\section{Materials and Methods}

Data on hypotensive drugs were taken from Morion research and retrieval system "Likarski zasoby" [4] for 2013-2014. Drugs for the analysis were selected on the basis of antihypertensive drugs included in the Unified Clinical Protocol of Medical Care to Patients with Hypertension for 2012 and recommended for the treatment of hypertension. They are presented in Table 1 [7].

To determine affordability of antihypertensive drugs, the coef- 


\section{Drugs for treating hypertension recommended by the unified clinical protocol}

\begin{tabular}{|l|l|}
\hline \multicolumn{2}{|c|}{ The I-st line antihypertensive drugs } \\
\hline \multicolumn{1}{|c|}{ PhT group } & \multicolumn{1}{c|}{ INN } \\
\hline ACE inhibitors & $\begin{array}{l}\text { Enalapril, Captopril, Quinapril, Lisinopril, Moexipril, Perindopril, Ramipril, } \\
\text { Spirapril, Fosinopril }\end{array}$ \\
\hline Angiotensin II receptor blockers & $\begin{array}{l}\text { Candesartan, Losartan, Olmesartan, Irbesartan, Eprosartan, Telmisartan, } \\
\text { Valsartan }\end{array}$ \\
\hline Long-lasting calcium antagonists & $\begin{array}{l}\text { Amlodipine, Lacidipine, Lercanidipine, Nifedipine, Felodipine, Diltiazem, } \\
\text { Verapamil }\end{array}$ \\
\hline$\beta$-Blockers & Atenolol, Betaxolol, Bisoprolol, Metoprolol, Nebivolol \\
\hline Diuretics & $\begin{array}{l}\text { Hydrochlorothiazide, Indapamide, Furosemide, Torasemide, Acetazolamide, } \\
\text { Spironolactone and Eplerenone }\end{array}$ \\
\hline
\end{tabular}

ficient of the solvency adequacy (Ca.s) and the affordability ratio (A) [3] were calculated by the formula I and II, respectively:

$$
\text { Ca.s }=\mathrm{P} / \mathrm{W}_{\text {a.w. }} \times 100 \% \text {, }
$$

where: $\mathrm{P}$ - is the weighted average price of 1 package of a drug for a certain period (a year);

$\mathrm{W}_{\text {a.w. }}$ - is the average wage for a certain period (a year) [6].

Ca.s determines the percentage of the average wage to be paid by the patient for the price of 1 package of a drug. The lower the value of Ca.s is, the more affordable the antihypertensive drug is for the patient. Drugs with Ca.s of more than $15 \%$ are of low affordability, from $5 \%$ to $15 \%$ - of average affordability and less than $5 \%$ - highly affordable.

$$
A=I_{x} \times Z_{\text {min }} /\left(I_{s} \times V_{k}\right) \text {, }
$$

where: $\mathrm{Z}_{\min }$ - is the minimum wage in the country;

$\mathrm{V}_{\mathrm{k}}$ - is the living wage;

$\mathrm{I}_{\mathrm{x}}$ - is the index of the minimum wage change $\left(\mathrm{I}_{\mathrm{x}}=\mathrm{Z}_{\mathrm{n}} / \mathrm{Z}_{\mathrm{n}-1}, \mathrm{Z}_{\mathrm{n}}\right.$ - is the wage within the year under study, $\mathrm{Z}_{\mathrm{n}-1}$ - is the minimum wage for the preceding year);

$\mathrm{I}_{\mathrm{s}}$ - is the consolidated index of the drug price for the same period $\left(I_{s}=C_{n} / C_{n-1}, C_{n}-\right.$ is the average price within the year under study, $\mathrm{C}_{\mathrm{n}-1}-$ is the average drug price for the preceding year).

The A ratio shows the relationship between the indexed minimum wage and the product between the living wage and the con- solidated index of the drug price. The affordability ratio is equal to one and is more satisfactory to provide availability of the drug to the public $(A \geq 1)$; it means that the minimum wage increases in proportion to the increase in the drug price, or even faster.

\section{Results and Discussion}

According to the analysis conducted 36 INNs and 35 combinations of the first line antihypertensive drugs recommended by the Unified Protocol for treating HTN were presented at the Ukrainian pharmaceutical market in 2013 and 2014. Availability of drugs increased in 2014. According to the coefficients of the solvency adequacy calculated (Tab. 2) the cost of 1 package of drugs studied for the Ukrainian patient was from
$0.19 \%$ (Furosemide) to $10.4 \%$ (Eplerenone) in 2013, and from $0.26 \%$ (Atenolol) to $12.9 \%$ (Eplerenone) of the average monthly wage - in 2014.

Eprosartan, Telmisartan, Eplerenone and 5 combination drugs were of average affordability for patients with HTN in 2013, and Olmesartan, Eprosartan, Eplerenone and 5 combination drugs (Fig.) in 2014. The following antihypertensive drugs were the most affordable both in 2013 and in 2014 for the Ukrainian patients:

- Furosemide-Ca.s 0.19\% (2013) and $0.51 \%$ (2014);

- Atenolol - Ca.s 0.21\% (2013) and $0.26 \%$ (2014);

- Propranolol-Ca.s 0.35\% (2013) and $0.47 \%$ (2014);

- Enalapril - Ca.s 0.52\% (2013) and $0.49 \%$ (2014).

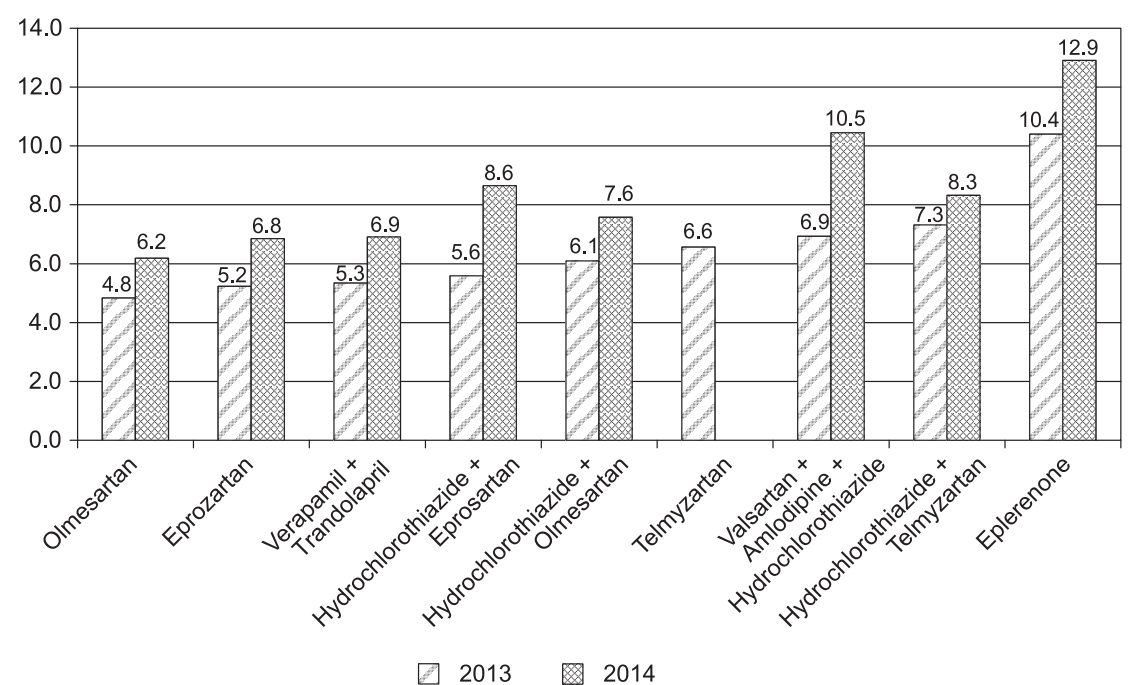

Fig. The least affordable antihypertensive drugs for patients in 2013-2014 by Ca.s 
Coefficients of the solvency adequacy and affordability ratios

\begin{tabular}{|c|c|c|c|c|c|}
\hline \multirow{2}{*}{ No. } & \multirow{2}{*}{ INN } & \multicolumn{2}{|c|}{ Ca.s } & \multirow{2}{*}{ A in $2012 / 2013$} & \multirow{2}{*}{$A$ in $2012 / 2013$} \\
\hline & & 2013 & 2014 & & \\
\hline 1 & 2 & 3 & 4 & 5 & 6 \\
\hline 1 & Hydrochlorothiazide & 0.6 & 0.76 & 0.98 & 0.81 \\
\hline 2 & Indapamide & 1.16 & 1.63 & 1.03 & 0.73 \\
\hline 3 & Furosemide & 0.19 & 0.51 & 0.95 & 0.37 \\
\hline 4 & Torasemide & 4.3 & 4.67 & 1.04 & 0.95 \\
\hline 5 & Spironolactone & 1.38 & 2.14 & 0.97 & 0.66 \\
\hline 6 & Eplerenone & 10.4 & 12.9 & 0.99 & 0.83 \\
\hline 7 & Amiloride + Hydrochlorothiazide & 1.5 & 1.8 & 1.09 & 0.86 \\
\hline 8 & Hydrochlorothiazide + Triamterene & 1.64 & 2.15 & 0.83 & 0.79 \\
\hline 9 & Propranolol & 0.35 & 0.47 & 0.94 & 0.76 \\
\hline 10 & Metoprolol & 1.2 & 1.3 & 1.25 & 0.99 \\
\hline 11 & Atenolol & 0.21 & 0.26 & 1.21 & 0.83 \\
\hline 12 & Betaxolol & 2.28 & 2.74 & 1.07 & 0.86 \\
\hline 13 & Bisoprolol & 1.0 & 1.26 & 1.23 & 0.82 \\
\hline 14 & Nebivolol & 1.91 & 2.0 & 1.29 & 0.98 \\
\hline 15 & Carvedilol & 1.61 & 2.12 & 1.02 & 0.78 \\
\hline 16 & Bisoprolol + Hydrochlorothiazide & 1,50 & 2.01 & 0.88 & 0.77 \\
\hline 17 & Atenolol + Chlorthalidone & 0.52 & 0.92 & 0.98 & 0.58 \\
\hline 18 & Felodipine + Metoprolol & 3.61 & 4.03 & 0 & 0.92 \\
\hline 19 & Amlodipine + Atenolol & 1.67 & 2.26 & 0.74 & 0.76 \\
\hline 20 & Atenolol + Nifedipine + Chlorthalidone & 1.37 & 1.61 & 1.0 & 0.88 \\
\hline 21 & Bisoprolol + Amlodipine & 2.46 & 3.53 & 1.15 & 0.72 \\
\hline 22 & Amlodipine & 1.52 & 1.66 & 0.92 & 0.95 \\
\hline 23 & Felodipine & 2.43 & 3.04 & 1.04 & 0.82 \\
\hline 24 & Nifedipine & 1.23 & 1.18 & 1.86 & 1.08 \\
\hline 25 & Lacidipine & 2.39 & 2.69 & 1.11 & 0.91 \\
\hline 26 & Lercanidipine & 2.97 & 4.32 & 1.25 & 0.71 \\
\hline 27 & Verapamil & 1.32 & 1.58 & 1.033 & 0.87 \\
\hline 28 & Diltiazem & 1.03 & 1.84 & 1.04 & 0.58 \\
\hline 29 & Amlodipine + Hydrochlorothiazide & 2.28 & 2.85 & 1.04 & 0.82 \\
\hline 30 & Captopril & 0.39 & 0.67 & 1.01 & 0.61 \\
\hline 31 & Enalapril & 0.52 & 0.49 & 1.16 & 1.1 \\
\hline 32 & Lisinopril & 0.89 & 1.05 & 1.26 & 0.88 \\
\hline 33 & Perindopril & 2.23 & 2.84 & 0.96 & 0.81 \\
\hline 34 & Ramipril & 1.99 & 2.3 & 1.04 & 0.89 \\
\hline 35 & Fosinopril & 1.52 & 1.91 & 1.13 & 0.82 \\
\hline 36 & Spirapril & 3.35 & 3.31 & 1.12 & 1.04 \\
\hline 37 & Moexipril & 2.26 & 3.13 & 0.84 & 0.74 \\
\hline 38 & Zofenopril & 1.54 & 2.19 & 0 & 0.72 \\
\hline 39 & Hydrochlorothiazide + Captopril & 0.45 & 0.57 & 1.0 & 0.81 \\
\hline 40 & Hydrochlorothiazide + Enalapril & 0.8 & 0.87 & 11.75 & 0.95 \\
\hline 41 & Enalapril + Indapamide & 1.16 & 1.18 & 1.04 & 1.01 \\
\hline
\end{tabular}


Continuation of Table 2

\begin{tabular}{|c|c|c|c|c|c|}
\hline 1 & 2 & 3 & 4 & 5 & 6 \\
\hline 42 & Hydrochlorothiazide + Lisinopril & 1.88 & 1.4 & 0.77 & 1.38 \\
\hline 43 & Indapamide + Perindopril & 2.8 & 3.54 & 1.04 & 0.87 \\
\hline 44 & Hydrochlorothiazide + Ramipril & 1.99 & 2.36 & 1.02 & 0.87 \\
\hline 45 & Hydrochlorothiazide + Quinapril & 2.18 & 3.07 & 1.01 & 0.73 \\
\hline 46 & Hydrochlorothiazide + Fosinopril & 1.92 & 2.6 & 1.09 & 0.76 \\
\hline 47 & Hydrochlorothiazide + Zofenopril & 3.04 & 4.2 & 0 & 0.75 \\
\hline 48 & Enalapril + Lercanidipine & 2.79 & 3.26 & 1.08 & 0.88 \\
\hline 49 & Amlodipine + Lisinopril & 2.36 & 2.79 & 1.12 & 0.86 \\
\hline 50 & Perindopril + Amlodipine & 2.61 & 3.28 & 1.37 & 0.82 \\
\hline 51 & Enalapril + Nitrendipine & 3.03 & 3.38 & 1.07 & 0.92 \\
\hline 52 & Ramipril + Amlodipine & 1.24 & 3.46 & 1.66 & 0.37 \\
\hline 53 & Amlodipine + Lisinopril & 2.36 & 1.883 & 1.09 & 1.29 \\
\hline 54 & Verapamil + Trandolapril & 5.34 & 6.9 & 1.0 & 0.8 \\
\hline 55 & Losartan & 1.52 & 1.92 & 1.07 & 0.81 \\
\hline 56 & Eprosartan & 5.23 & 6.84 & 1.08 & 0.79 \\
\hline 57 & Valsartan & 2.84 & 3.8 & 1.09 & 0.77 \\
\hline 58 & Irbesartan & 3.18 & 3.14 & 1.9 & 1.04 \\
\hline 59 & Candesartan & 2.44 & 2.54 & 1.15 & 0.99 \\
\hline 60 & Telmisartan & 6.56 & 4.49 & 1.07 & 1.5 \\
\hline 61 & Olmesartan & 4.83 & 6.18 & 1.07 & 0.8 \\
\hline 62 & Hydrochlorothiazide + Losartan & 2.28 & 3.0 & 1.09 & 0.78 \\
\hline 63 & Hydrochlorothiazide + Eprosartan & 5.59 & 8.64 & 0 & 0.66 \\
\hline 64 & Valsartan + Hydrochlorothiazide & 3.04 & 3.68 & 1.15 & 0.85 \\
\hline 65 & Hydrochlorothiazide + Irbesartan & 4.51 & 4.38 & 1.11 & 1.06 \\
\hline 66 & Hydrochlorothiazide + Candesartan & 3.42 & 3.68 & 1.11 & 0.96 \\
\hline 67 & Hydrochlorothiazide + Telmisartan & 7.31 & 8.32 & 1.05 & 0.91 \\
\hline 68 & Hydrochlorothiazide + Olmesartan & 6.09 & 7.57 & 1.03 & 0.83 \\
\hline 69 & Valsartan + Amlodipine & 3.76 & 4.61 & 0.98 & 0.84 \\
\hline 70 & Losartan + Amlodipine & 1.91 & 1.85 & 1.08 & 1.06 \\
\hline 71 & Valsartan + Amlodipine + Hydrochlorothiazide & 6.92 & 10.45 & 0 & 0.68 \\
\hline
\end{tabular}

According to the results of the calculation of affordability ratios (A) (Table 2) of the drugs studied 9 INNs and 5 combinations of drugs had the affordability ratio less than one in 2013, and 32 INNs and 28 combinations of drugs - in 2014. It indicates the sharp decrease in affordability of antihypertensive drugs for the Ukrainian patients in 2014. Combinations of Hydrochlorothiazide with Lisinopril and Amlodipine with Lisinopril, as well as Telmisartan became more affordable in 2014 as compared to 2013.

\section{CONCLUSIONS}

The analysis has shown that practically there are no changes in the range of drugs to treat hypertension recommended by the Unified Clinical Protocol of Hypertension Treatment of 2012 at the pharmaceutical market of Ukraine in 2014 as compared to 2013. According to the coefficients of the solvency adequacy calculated the most affordable for Ukrainian patients in 2013 - 2014 were the drugs of the following INNs: Furosemide, Atenolol, Propranolol and Enalapril. According to affordability ratios 8 INNs and 6 combinations of drugs had $D<1$ in 2013, and 15 INNs and 16 combinations of drugs - in 2014. It indicates the sharp decrease in affordability of antihypertensive drugs for the Ukrainian patients in 2014. 


\title{
REFERENCES
}

1. Дослідницько-пошукова система «Лекарственные средства» компанії «Моріон». Дані за 2013$2014 \mathrm{pp}$.

2. Загородний M.І., Свінціцький А.С., Казак Л.І. та ін. Рациональная фармакотерапия. - К.: Національний медичний університет ім. О.О.Богомольця. - С. 502.

3. Налетов С.В., Зупанец И.А., Бахтеева Т.Д. и др. Клиническая фармакология: Учеб. пособие. - Х.: НФАУ, 2005. - $448 \mathrm{c}$.

4. Мазур Н.А. Основы клинической фармакологии и фармакотерапии в кардиологии. - М.: Медицина, 1992. - 304 c.

5. Свищенко Е.П., Коваленко В.Н. Артериальная гипертензия: Практическое руководство / Под ред. В.Н.Коваленко. - К.: МОРИОН, 2001. - 528 с.

6. Укрстат. Режим доступу: http: // www.ukrstat.gov.ua/

7. Уніфікований клінічний протокол надання медичної допомоги хворим з артеріальною гіпертензією. - К., 2012. - 61 с.

8. Яковлева Л.В., Бездетко Н.В., Герасимова О.А. и др. Фармакоэкономика: Учеб. пособие / Под ред. проф. Л.В.Яковлевой. - Х.: Изд-во НФаУ, 2009. - 158 с.

\section{АНАЛІЗ ДОСТУПНОСТІ АНТИГІПЕРТЕНЗИВНИХ ПРЕПАРАТІВ ПЕРШОЇ ЛІНІЇ ДЛЯ УКРАЇНСЬКИХ ПАЦІЄНТІВ Л.В.Яковлєва, М.М.Портянка}

\section{Національний фармацевтичний університет}

Ключові слова: гіпертонічна хвороба; показник адекватності платоспроможності; коефіцієнт доступності; уніфікований клінічний протокол

\begin{abstract}
Гіпертонічна хвороба є однією з найважливіших медичних і соціальних проблем яку нашій країні, так і в усьому світі в силу своєї значної поширеності і тяжких наслідків, що і визначило об'єкт і мету даного дослідження. Метою дослідження було визначення доступності для українських пацієнтів антигіпертензивних препаратів першої лінії, рекомендованих «Уніфікованим клінічним протоколом медичної допомоги хворим з артеріальною гіпертензією» (УКПМД) і представлених на фармацевтичному ринку України у 2013-2014 роках. Для характеристики ступеня доступності антигіпертензивних лікарських засобів використовували два показники: Са.s. та D. Показник Ca.s визначає \% середньої заробітної плати українця, необхідний для покупки однієї упаковки препарату, чим більше значення він має, тим менш доступний препарат. Коефіцієнт доступності D показує співвідношення між зростанням прожиткового мінімуму з урахуванням індексу росту ціни на препарат та зростання мінімальної заробітної плати. Проведені дослідження дозволили встановити, що протягом 2013-2014 років на фармацевтичному ринку України були представлені антигіпертензивні ЛП (ТН) першої лінії на основі 36 МНН та 35 фіксованих комбінацій. У 2014 році за усіма МНН та для усіх комбінацій спостерігаємо збільшення показника Ca.s, що свідчить про тенденцію до зниження доступності ЛП. Але за абсолютною величиною більшість значень Ca.s ще знаходиться у проміжку високодоступних лікарських препаратів, що забезпечується наявністю великої кількості генеричних препаратів на ринку. Динаміка значень D також підтвердила тенденцію до зниження доступності антигіпертензивних ЛП та їх комбінацій. Так, у 2013 році D<1 мали 9 МнН і 5 комбінацій, а у 2014 році - 32 МНН та 28 комбінацій. Встановлена тенденція до зниження доступності ЛП обумовлює необхідність введення соціально-економічних заходів для підтримки збіднілого населення України, серед яких може бути реімбурсація витрат на гіпотензивну терапію за рахунок держави.
\end{abstract}

\section{АНАЛИЗ ДОСТУПНОСТИ АНТИГИПЕРТЕНЗИВНЫХ ПРЕПАРАТОВ ПЕРВОЙ ЛИНИИ ДЛЯ УКРАИНСКИХ ПАЦИЕНТОВ}

Л.В.Яковлева, М.М. Портянка

Национальный фармацевтический университет

Ключевые слова: гипертоническая болезнь; показатель адекватности платежеспособности; коэффициент доступности; унифицированный клинический протокол

\footnotetext{
Гипертоническая болезнь является одной из важнейших медицинских и социальных проблем как в нашей стране, так и во всем мире в силу своей значительной распространенности и тяжелых последствий, что определило объект и цель данного исследования. Целью исследования было определение доступности для украинских пациентов антигипертензивных препаратов первой линии, рекомендованных «Унифицированным клиническим протоколом медицинской помощи больным с артериальной гипертензией» (УКПМП) и представленных на фармацевтическом рынке Украины в 2013-2014 годах. Для характеристики степени доступности антигипертензивных лекарственных средств использовали два показателя: Са.s. и D. Показатель Са.s определяет \% средней
} 
заработной платы украинцев, необходимый для покупки одной упаковки препарата, чем большее значение он имеет, тем менее доступен препарат. Коэффициент доступности D показывает соотношение между ростом прожиточного минимума с учетом индекса роста цены на препарат и ростом минимальной заработной платы. Проведенные исследования позволили установить, что в течение 2013-2014 годов на фармацевтическом рынке Украины были представлены антигипертензивные ЛП (ТН) первой линии на основе 36 МнН и 35 фиксированных комбинаций. В 2014 году по всем МНН и для всех комбинаций наблюдаем увеличение показателя Са.s, что свидетельствует о тенденции к снижению доступности ЛП. Но по абсолютной величине большинство значений Ca.s еще находится в промежутке высокодоступных лекарственных препаратов, что обеспечивается наличием большого количества генерических препаратов на рынке. Динамика значений D также подтвердила тенденцию к снижению доступности антигипертензивных ЛП и их комбинаций. Так, в 2013 году D<1 имели 9 МнН и 5 комбинаций, а в 2014 году - 32 МНН и 28 комбинаций. Установленная тенденция к снижению доступности ЛП обусловливает необходимость введения социально-экономических мероприятий для поддержания обедневшего населения Украины, среди которых может быть реимбурсация затрат на гипотензивную терапию за счет государства.

Address for correspondence:

Received in 11.04.2016

4, Valentynivska str., Kharkiv, 61168, Ukraine.

Tel. (572) 65-88-95. E-mail: ph-econom@nuph.edu.ua.

National University of Pharmacy 